\title{
The flux of carbonyl sulfide and carbon disulfide between the atmosphere and a spruce forest
}

\author{
X. Xu ${ }^{1, *}$, H. G. Bingemer ${ }^{1}$, and U. Schmidt ${ }^{1}$ \\ ${ }^{1}$ Institute for Meteorology and Geophysics, University of Frankfurt, P.O. Box 111932, 60054 Frankfurt am Main, Germany \\ *now at Max Planck Institute for Chemistry, Mainz, Germany
}

Received: 9 January 2002 - Published in Atmos. Chem. Phys. Discuss.: 21 February 2002

Revised: 27 May 2002 - Accepted: 25 June 2002 - Published: 10 July 2002

\begin{abstract}
Turbulent fluxes of carbonyl sulfide (COS) and carbon disulfide $\left(\mathrm{CS}_{2}\right)$ were measured over a spruce forest in Central Germany using the relaxed eddy accumulation (REA) technique. A REA sampler was developed and validated using simultaneous measurements of $\mathrm{CO}_{2}$ fluxes by REA and by eddy correlation. REA measurements were conducted during six campaigns covering spring, summer, and fall between 1997 and 1999. Both uptake and emission of COS and $\mathrm{CS}_{2}$ by the forest were observed, with deposition occurring mainly during the sunlit period and emission mainly during the dark period. On the average, however, the forest acts as a sink for both gases. The average fluxes for $\operatorname{COS}$ and $\mathrm{CS}_{2}$ are $-93 \pm 11.7 \mathrm{pmol} \mathrm{m}^{-2} \mathrm{~s}^{-1}$ and $-18 \pm$ $7.6 \mathrm{pmol} \mathrm{m}^{-2} \mathrm{~s}^{-1}$, respectively. The fluxes of both gases appear to be correlated to photosynthetically active radiation and to the $\mathrm{CO}_{2}$ and $\mathrm{H}_{2} \mathrm{O}$ fluxes, supporting the idea that the air-vegetation exchange of both gases is controlled by stomata. An uptake ratio $\mathrm{COS} / \mathrm{CO}_{2}$ of $10 \pm 1.7 \mathrm{pmol} \mu \mathrm{mol}^{-1}$ has been derived from the regression line for the correlation between the $\mathrm{COS}$ and $\mathrm{CO}_{2}$ fluxes. This uptake ratio, if representative for the global terrestrial net primary production, would correspond to a sink of $2.3 \pm 0.5 \mathrm{Tg} \mathrm{COS} \mathrm{yr}^{-1}$.
\end{abstract}

\section{Introduction}

The tropospheric abundance $(\sim 500 \mathrm{ppt})$ and long tropospheric lifetime (2-7 years) of carbonyl sulfide (COS) makes it the major source of the stratospheric background aerosol (Crutzen, 1976; Engel and Schmidt, 1994), which plays a role in the Earth's radiation budget and in heterogeneous reactions causing chemical ozone destruction (Lacis et al., 1992; Rodriguez et al., 1991; Grainier and Brasseur, 1992).

$\mathrm{COS}$ is released to the atmosphere by oceans, biomass burning, oxidation of $\mathrm{CS}_{2}$ and DMS, and several anthro-

Correspondence to: X. Xu (xu@mpch-mainz.mpg.de) pogenic sources (tire wear, aluminium production, coal combustion, sulfur recovery, etc.), and is removed by terrestrial vegetation, soils, photolysis, and reactions with $\mathrm{OH}$ and O radicals (Khalil and Rasmussen, 1984; Chin and Davis, 1993; Andreae and Crutzen, 1997; Watts, 2000). Terrestrial vegetation is recognized as a dominant sink of atmospheric COS, but the magnitude of this sink has not been satisfactorily quantified. The uptake of COS by vegetation was first observed by Taylor et al. (1983) and Kluczewski et al. (1983, 1985) during laboratory chamber experiments with synthetic air containing $120 \mathrm{ppb}$ and $4 \mathrm{ppb}$ of COS, respectively. Brown and Bell (1986) obtained a preliminary estimate of the global vegetation sink of $2-5 \mathrm{Tg} \mathrm{COS} \mathrm{yr}^{-1}$, based on data from Kluczewski etal. (1983, 1985). However, air-vegetation exchange of COS depends on the mixing ratio level of this gas (e.g. Kesselmeier and Merk, 1993). Therefore, estimates of the global COS uptake by vegetation that are derived from experiments employing largely enhanced COS levels will not be representative of the real natural conditions. Laboratory experiments with crops conducted by Goldan et al. (1988) showed that the uptake of COS and $\mathrm{CO}_{2}$ for atmospheric levels and under daylight conditions has a common pathway, i.e., through the open stomata, and that the transport resistances for both gases are virtually the same. This similarity led Goldan et al. (1988) to estimate the COS vegetation sink on the basis of the atmospheric mixing ratios of $\mathrm{COS}$ and $\mathrm{CO}_{2}$ and the primary productivity of terrestrial plants. They reported an uptake rate ranging from 0.2 to $0.6 \mathrm{Tg} \mathrm{COS} \mathrm{yr}{ }^{-1}$, one order of magnitude smaller than the estimate of Brown and Bell (1986).

Enzymological studies revealed that all enzymes involved in $\mathrm{CO}_{2}$ assimilation can metabolize $\mathrm{COS}$, with carbonic anhydrase (CA) being the key enzyme which catalyzes the hydrolysis of $\mathrm{COS}$ to $\mathrm{CO}_{2}$ and $\mathrm{H}_{2} \mathrm{~S}$ (Protoschill-Krebs and Kesselmeier, 1992; Protoschill-Krebs et al., 1995, 1996). According to this finding, all living higher plants should be able to consume COS. This view is consistent with labo- 


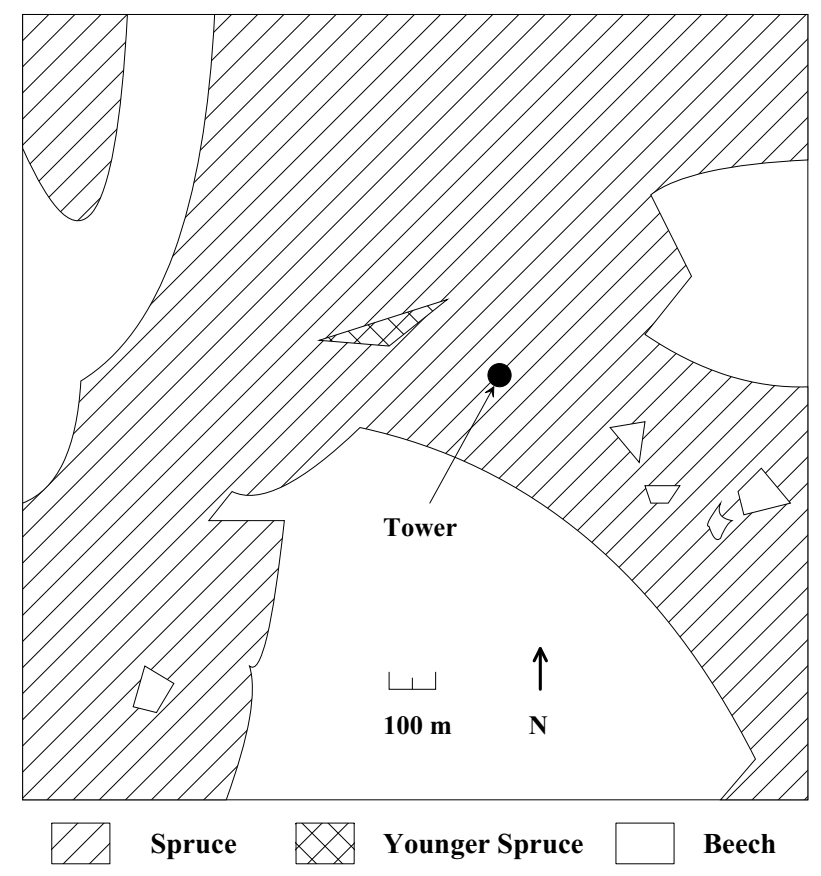

Fig. 1. Forest stands around the experimental site.

ratory results (Kluczewski et al., 1983, 1985; Taylor et al., 1983; Goldan et al., 1988; Fried et al., 1993; Kesselmeier and Merk, 1993). However, it is not generally supported by field studies. While some in-situ experiments clearly showed uptake of COS by plants or soil/plant systems (Mihalopoulos et al., 1989; Hofmann et al., 1992; Bartell et al., 1993; Dippel and Jaeschke, 1996; Kuhn et al., 1999), other measurements found either no evidence of deposition (Berresheim and Vulcan, 1992) or the existence of both deposition and emission (Kesselmeier et al., 1993; Hofmann, 1993; Huber, 1994). This indicates that the role of vegetation under natural conditions is more complicated. The air-plant exchange of COS appears to be bidirectional and dependent on the ambient COS mixing ratio, the environmental conditions, the plant type, etc. A compensation point, at which deposition equals emission, was observed during experiments of the air-plant exchange of COS (Rennenberg et al., 1991; Kesselmeier and Merk, 1993; Huber, 1994; Dippel and Jaeschke, 1996). It varies from 90 to $515 \mathrm{ppt}$ and is usually lower than the tropospheric level of COS ( 500 ppt), suggesting that vegetation tends to take up COS in most cases. The air-plant exchange flux of COS was often found to be correlated to the $\mathrm{CO}_{2}$ assimilation rate, to photosynthetically active radiation (PAR) and to the $\mathrm{H}_{2} \mathrm{O}$ flux (Kesselmeier and Merk, 1993; Kesselmeier et al., 1993; Bartell et al., 1993; Hofmann, 1993; Huber, 1994), implying the importance of plant physiological processes in controlling the COS exchange rate. The close relationship between $\mathrm{COS}$ uptake and $\mathrm{CO}_{2}$ fixation is an encouraging finding, as it allows an estimate of the global veg- etation sink of COS on the basis of the observed uptake ratio $\mathrm{COS} / \mathrm{CO}_{2}$ and the terrestrial plant productivity. Assuming that the ratio of the $\mathrm{COS}$ and $\mathrm{CO}_{2}$ uptake equals the ratio of the atmospheric burden of both gases, Kesselmeier and Merk (1993) obtained a vegetation sink of $0.86-1.0 \mathrm{Tg} \operatorname{COS} \mathrm{yr}^{-1}$. This figure is at the high end of the estimated range of 0.16$0.91 \mathrm{Tg} \mathrm{COS} \mathrm{yr}^{-1}$ reported by Chin and Davis (1993). However, the actual value of this COS sink might be larger, since it was observed that the plants investigated prefer to take up $\mathrm{COS}$ over $\mathrm{CO}_{2}$, as indicated by Kesselmeier and Merk (1993).

Only a few studies have been made on the air-plant exchange of $\mathrm{CS}_{2}$. Most of the earlier studies (Adams et al., 1981; Steudler and Peterson, 1985; Goldan et al., 1987; Lamb et al., 1987; Hines and Morrison, 1992) reported emission of $\mathrm{CS}_{2}$ from vegetated soils. Castro and Galloway (1991) demonstrated that those chamber measurements employing sulfur-free sweep gases resulted in artificial release of $\mathrm{CS}_{2}$ and COS. During the experiments of Taylor et al. (1983), vegetation uptake was observed at a high $\mathrm{CS}_{2}$ level of $120 \mathrm{ppb}$. Fall et al. (1988) found indirect evidence for the uptake of $\mathrm{CS}_{2}$ by wheat at lower ambient levels. Gradient measurements of sulfur gases in a loblolly pine forest did not reveal any evidence of $\mathrm{CS}_{2}$ uptake by the trees (Berresheim and Vulcan, 1992). More recent field and laboratory studies (Hofmann, 1993; Kesselmeier et al., 1993; Huber, 1994; Dippel and Jaeschke, 1996) indicate that $\mathrm{CS}_{2}$ is both deposited to and emitted from soil/plant systems. It is presently not clear which physiological process influences and controls the exchange of $\mathrm{CS}_{2}$ between the atmosphere and plants.

Considering the high variability of the exchange rates of $\mathrm{COS}$ and $\mathrm{CS}_{2}$ between the atmosphere and terrestrial plants, present databases are obviously not adequate to allow a reliable estimate of global vegetation sinks for both gases. More field measurements on major ecosystems are required to improve our understanding of the role of terrestrial vegetation in the atmospheric cycle of $\mathrm{COS}$ and $\mathrm{CS}_{2}$.

Dynamic enclosure and gradient methods are commonly used for measuring COS uptake by plants. In the former, the chamber disturbs the natural microclimate and the results have only a limited spatial representativity. The latter method overcomes these problems and measures the surface fluxes on an ecosystem scale, but the assumptions of the gradient method are not always tenable. The method is not recommended for measuring the surface fluxes over tall vegetation, such as forests (den Hartog and Neumann, 1984). The widely adopted eddy correlation (EC) method needs fast-response sensors, which are unavailable for many species. A modified method, the relaxed eddy accumulation (REA), also known as conditional sampling (CS), overcomes the need for fastresponse sensors and has proven a promising technique for measuring fluxes using slow-response gas sensors (Oncley et al., 1993; Pattey et al., 1993, 1999; Beverland et al., 1996; Moncrieff et al., 1998). According to Businger and Oncley 
(1990), the gas flux is expressed as

$F_{c}=\beta \sigma_{w}\left(\overline{c^{+}}-\overline{c^{-}}\right)$,

where $\overline{c^{+}}$and $\overline{c^{-}}$are the average concentrations ( $\mathrm{pmol} \mathrm{m}^{-3}$ ) associated with updrafts and downdrafts, respectively, $\beta$ is a dimensionless coefficient, and $\sigma_{w}$ is the standard deviation of the vertical windspeed $\left(\mathrm{m} \mathrm{s}^{-1}\right)$.

We have developed a REA sampler and used it to measure $\mathrm{COS}$ and $\mathrm{CS}_{2}$ fluxes over a spruce forest. In the following sections we present some details of the REA sampler and its validation. The measurements of the $\mathrm{COS}$ and $\mathrm{CS}_{2}$ fluxes by REA are discussed.

\section{Experimental}

\subsection{Site}

Measurements were made on a plateau in the Solling Mountains, Germany $\left(51^{\circ} 46^{\prime} \mathrm{N}, 9^{\circ} 35^{\prime} \mathrm{E}, 505 \mathrm{~m}\right.$ a.s.l). The plateau extends about $1300 \mathrm{~m}$ and has a slight downward slope of $1^{\circ} 20^{\prime}$ towards east. Fig. 1 shows a scheme of the research site. REA flux measurements were taken from a $52 \mathrm{~m}$ meteorological tower of the Institute for Bioclimatology (IFB), University of Göttingen.

The site is covered mainly by Norway Spruce (Picea abies) planted in 1888 , with a tree density of 461 trees ha $^{-1}$ (Ellenberg et al., 1986). The average canopy height of the spruce stand is about $30 \mathrm{~m}$ and the leaf area index is about 7. A beech stand (Fagus sylvatica) with a canopy height of about $29 \mathrm{~m}$ is located south and southwest of the tower. The small triangle-shaped area located about $200 \mathrm{~m}$ northwest of the tower represents younger spruces of about $20 \mathrm{~m}$ height. There are some beech patches to the southeast of the tower. If these beech patches are neglected, the spruce fetch extends $200-300 \mathrm{~m}$ in the south and southwest directions and up to $600-1500 \mathrm{~m}$ in other directions from the tower (Ibrom et al., 1996). The largest source area extent (or the footprint) of the site, i.e., the maximum upwind distance from which the observed flux can originate, has been estimated by Laubach et al. (1994) and Ibrom et al. (1996). For the measurement height of this work $(39 \mathrm{~m})$, Laubach et al. (1994) predicted that $80 \%$ of the flux originates from a distance between 0 and $600 \mathrm{~m}$ under neutral conditions. Taking the influence of stability on the source area into account, Ibrom et al. (1996) obtained a maximum extent of the source area ranging from $200 \mathrm{~m}$ during daytime to $600 \mathrm{~m}$ during the night. Therefore, the fetch requirements for flux measurements are met during daytime even in the worst case, i.e., southwest wind. Inhomogeneous fetch may be encountered during nocturnal measurements, which only account for $2 \%$ of flux measurements in this work.

Soils at the site are characterized as cambisol with a $\mathrm{pH}$ value of 3.5 (Ellenberg et al., 1986). The soils are covered by a humus layer of $5 \mathrm{~cm}$ depth. Herbs, such as Trientalis

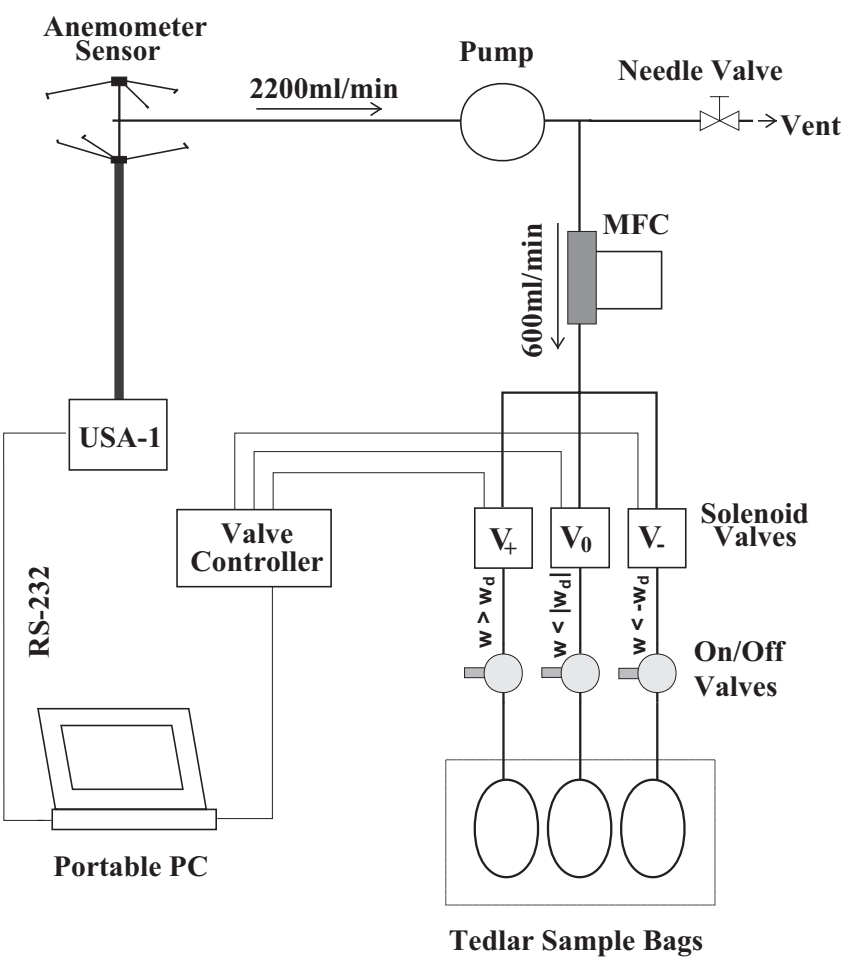

Fig. 2. Schematic view of the REA sampler.

europea, Avenella flexuosa, Galium harcynium, are the dominant ground plants. They cover $40 \%$ of the area. In addition, about $10 \%$ of the ground is covered by moss species, such as Dicranella heteromalla, Polytrichum formosum, etc.

The climate of the site is characterized as montane (suboceanic / sub-continental). The annual mean temperature is $6.6^{\circ} \mathrm{C}$. The maximum and minimum monthly mean temperatures are approximately $18^{\circ} \mathrm{C}$ (July) and $4^{\circ} \mathrm{C}$ (February), respectively. The annual precipitation is about $1045 \mathrm{~mm}$, with relatively large interannual variations. There is no clear dry or wet season at the site. The prevailing wind direction is west. More details about the site are described by Ellenberg et al. (1986), Laubach et al. (1994), and Ibrom et al. (1996).

\subsection{Sampling}

Samples were collected at a platform at $39 \mathrm{~m}$ altitude using a REA sampler depicted in Fig. 2. A 3-dimensional sonic anemometer-thermometer with a USA-1 sensor (Metek) was used for monitoring wind components and the virtual temperature. Wind and temperature data were recorded at a rate of $10 \mathrm{~Hz}$. Three computer controlled Teflon solenoid valves (Cole Parmer) were employed to direct upstream and downstream air into two different sample reservoirs.

Bags with a volume of $9 \mathrm{~L}$, made of Tedlar PVF film ( $5 \mu \mathrm{m}$, Du Pont), were used as sample reservoirs. They were protected by polystyrene boxes, which on one hand prevented photochemical reactions in the samples, and on 


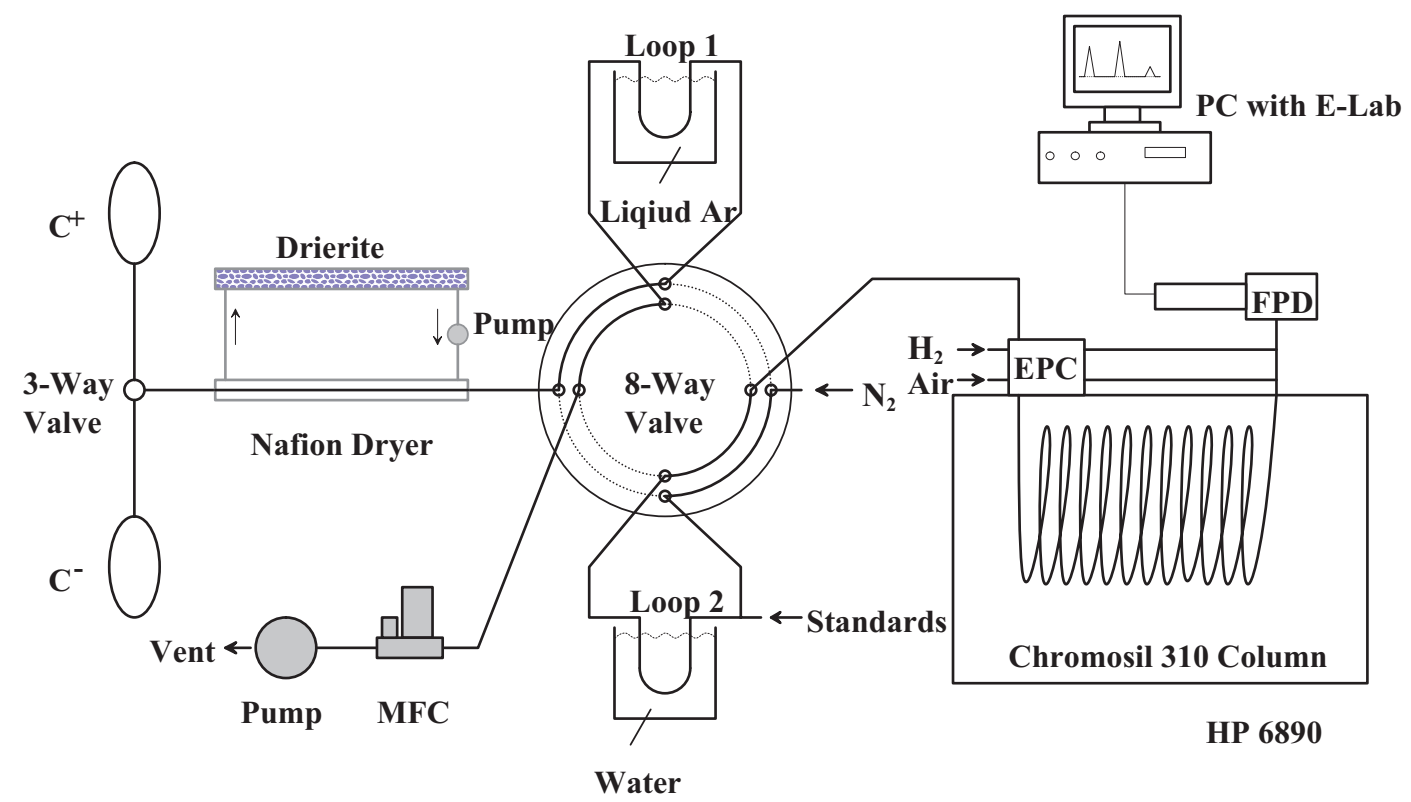

Fig. 3. System for the analysis of sulfur gases in air samples collected in Tedlar bags.

the other hand could easily be transported. Before sampling, the bags were evacuated and then connected to the solenoid valves. During sampling, air from the height of the anemometer sensor was drawn at a rate of $2200 \mathrm{ml} \mathrm{min}^{-1}$ through a $3 \mathrm{~m}$ Teflon FEP tubing (1/8" O. D., 1/16" I. D.) by a Teflon diaphragm pump (N86 KTE, KNF Neuberger). This flow of compressed air was split in two sub-streams. A flow of $600 \mathrm{ml} \mathrm{min}^{-1}$, set by a mass flow controller (MFC, $0-1000 \mathrm{ml} \mathrm{min}^{-1}$, Bronk Horst), was directed to the selected reservoir, and the remainder was vented.

The sampling period was $30 \mathrm{~min}$. The effective sampling time was, however, less than $30 \mathrm{~min}$, because a deadband $\left(w_{d}\right)$ was applied, i.e. an interval of the vertical wind speed in which air was not accumulated in the reservoir for up or downdraft, if $|w| \leq w_{d}$. The use of a deadband increases the concentration differences between the two sample reservoirs and prolongs the lifetime of the valves (Pattey et al., 1993; Oncley et al., 1993; Valentini et al., 1997; Xu, 2001). To establish a suitable deadband, a test run (3-5 min) was made before each REA sampling. The turbulence intensity $\left(\sigma_{w}\right)$, as derived from the vertical wind data during the test run, was taken as a reference to select the value of $w_{d} . w_{d}$ was usually set to less than $0.2 \sigma_{w}$, corresponding to an effective sampling period of $25-30 \mathrm{~min}$.

Although the sampling system can be operated at $10 \mathrm{~Hz}$, the valves were switched at $5 \mathrm{~Hz}$, with a few exceptions only. This prolongs the valve's lifetime without significant reduction in the accuracy of the flux measurements. This is confirmed by the good agreement between the sensible heat fluxes obtained by REA simulations at sampling frequencies $5 \mathrm{~Hz}$ and $10 \mathrm{~Hz}$, respectively (Xu, 2001).

The lag time, i.e. the travel time of air from the intake point to the switching valve, is estimated to be $1.0 \mathrm{~s}$, based on the flow rates and dead volume of the tubing. This lag time was taken into account in the control program.

Damping of concentration fluctuations in the tubing due to mixing may cause an underestimate of flux. However, an estimate of this effect using formulae of Leuning and Moncrieff (1990) showed that the reduction of flux is negligible even under extreme conditions. Therefore, no correction of the damping effect is necessary. More details about this REA sampler are discussed in $\mathrm{Xu}(2001)$

\subsection{Sample analysis}

Air samples were analyzed for $\mathrm{COS}, \mathrm{CS}_{2}$ and $\mathrm{CO}_{2}$ within 3 hour after sampling. The inertness of the Tedlar film ensures that loss and production of these trace gases in the bags are negligible during storage. Ambient air can be stored in the bags for more than $10 \mathrm{~h}$ without significant changes in the $\mathrm{COS}$ and $\mathrm{CS}_{2}$ contents (Xu, 2001)

$\mathrm{COS}$ and $\mathrm{CS}_{2}$ were measured using a gas chromatograph (GC, HP 6890, Hewlett Packard) with a flame photometric detector (FPD, Tracor). Figure 3 shows the analyzing system. The mixing ratios of $\mathrm{COS}$ and $\mathrm{CS}_{2}$ in the bags were measured by multiple analysis of $0.4-0.5 \mathrm{~L}$ aliquots from the bags. Each bag was analyzed at least 3 times. Samples were cryogenically focused (liquid Argon, $-186^{\circ} \mathrm{C}$ ) in a capillary glass trap $(20 \mathrm{~cm} \times 2 \mathrm{~mm} \mathrm{I}$. D.) filled with $2-3 \mathrm{~cm}$ silanized glasswool. Water vapor in the air samples was removed by passing the sample through a Nafion dryer (Perma Pure, KNF Neuberger), operated with a counterflow of dry air (Drierite, Cole Parmer). This method has proved to be effective and economical. 
The sulfur compounds were separated on a $5^{\prime} \times 1 / 8^{\prime \prime}$ Teflon column packed with Chromosil 310 (Supelco). Nitrogen (99.999\%, Messer Griesheim) was used as a carrier gas. For optimal separation within a short time (4-5 min), a pressure program was used instead of the conventional temperature program. The carrier gas pressure at the inlet of the column was controlled by the electronic pneumatic control (EPC) of the GC. The oven temperature was set to $30 \pm 0.1^{\circ} \mathrm{C}$. A typical pressure program was: (1) start at $280 \mathrm{kPa}$ and hold for $0.1 \mathrm{~min}$, (2) decrease to $120 \mathrm{kPa}$ at a rate of $240 \mathrm{kPa} \mathrm{min}^{-1}$ and hold for $2 \mathrm{~min}$, and (3) increase to $340 \mathrm{kPa}$ at a rate of $1000 \mathrm{kPa} \mathrm{min}^{-1}$ and holding for $1.7 \mathrm{~min}$.

The GC/FPD system was calibrated daily by injecting standard samples with a gas tight Teflon/glass syringe (Precision sampling Corp.). The standard gas mixture (0.6-1 ppm $\mathrm{COS}$ and $0.1-0.25 \mathrm{ppm} \mathrm{CS}_{2}$ ) was produced by a permeation dilution device kept at $30 \pm 0.1^{\circ} \mathrm{C}$ (Haunold). The permeation rates were determined by weighing the permeation tubes (VICI Metronics) every one or two months with an electronic balance $(0.01 \mathrm{mg}$, Sartorius). The relative standard deviation of the permeation rates is less than $10 \%$.

Most of the samples were also analyzed for $\mathrm{CO}_{2}$, using a Li-6262 infrared $\mathrm{CO}_{2} / \mathrm{H}_{2} \mathrm{O}$ analyzer (LI-COR). Pressure changes in the sample cell were measured by a pressure transducer (6262-03, LI-COR). The LI-6262 was programmed to automatically correct for the influence of pressure and $\mathrm{H}_{2} \mathrm{O}$ fluctuations on $\mathrm{CO}_{2}$ measurements due to dilution and pressure broadening. Slight zero and span drifts were corrected using working standards, which were calibrated against secondary standards at the Institute for Stratospheric Chemistry, Research Center Jülich, Germany, that can be traced to the Scripps $\mathrm{CO}_{2}$ calibration scale.

\subsection{Other measurements}

Continuous eddy correlation measurements of the $\mathrm{CO}_{2}, \mathrm{H}_{2} \mathrm{O}$ and heat fluxes as well as measurements of meteorological parameters were conducted by the IFB. The EC measurements of the $\mathrm{CO}_{2}$ and $\mathrm{H}_{2} \mathrm{O}$ fluxes were made at the same height as the REA sampling, at $39 \mathrm{~m}$ above the ground. The same sonic anemometer-thermometer was used for the EC and REA measurements. The sensor of the instrument was mounted at the end of a metal bar of $2.5 \mathrm{~m}$ length, which was pointed towards west. The $\mathrm{CO}_{2}$ and $\mathrm{H}_{2} \mathrm{O}$ mixing ratios at the height of the sonic sensor were continuously measured at $10 \mathrm{~Hz}$, using a second LI-6262. An automatic daily two point calibration of the system was made for both $\mathrm{CO}_{2}$ and $\mathrm{H}_{2} \mathrm{O}$, using $\mathrm{CO}_{2}$ calibration gases and a stable capacitive humidity sensor, respectively. More details about the instrumentation and the EC measurements were described by Laubach et al. (1994) and Ibrom et al. (1996).

The fluxes of $\mathrm{COS}$ and $\mathrm{CS}_{2}$ between the soil and the atmosphere were measured at several positions within $30 \mathrm{~m}$ distance from the tower. Three dynamic chambers in parallel were exposed to the ground. The chambers were flushed with

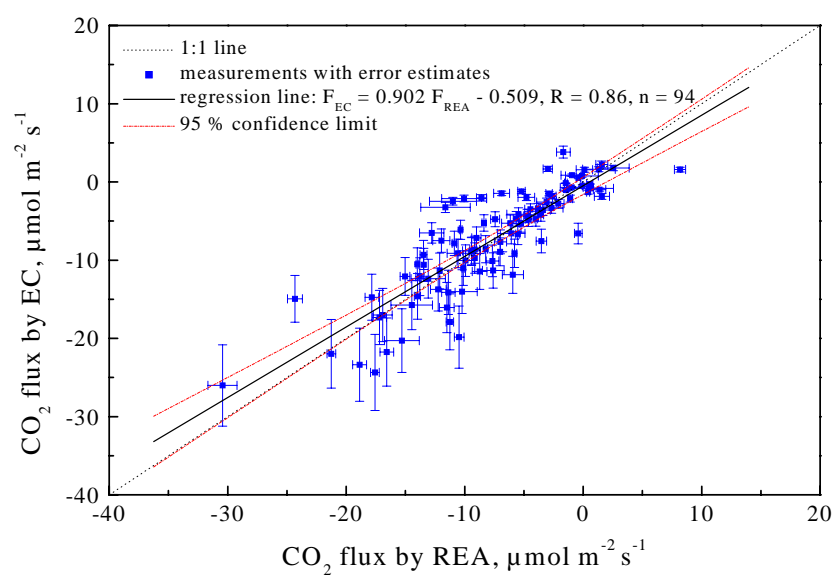

Fig. 4. Intercomparison of the $\mathrm{CO}_{2}$ fluxes obtained by REA with those from EC measurements.

ambient air. Air samples of the in- and outflow of the chambers were collected in Tedlar bags, and analyzed as described in Sect. 2.3. The results are reported in detail by Steinbacher (2000) and Steinbacher et al. (2002)

\subsection{Assessment of errors}

The turbulent flux $F_{c}$ of a trace gas $c$ was calculated using Equation 1. $\sigma_{w}$ and $\beta$ are derived from wind and temperature data measured by the sonic anemometer-thermometer. $\overline{c^{+}}$and $\overline{c^{-}}$are obtained as averages of at least three concentration measurements in samples of the respective bags.

According to the error propagation theory, the relative systematic error in $F_{c}$ may be estimated by

$$
\frac{\Delta F_{c}}{F_{c}}=\frac{\Delta \sigma_{w}}{\sigma_{w}}+\frac{\Delta \beta}{\beta}+\frac{\Delta\left(\overline{c^{+}}-\overline{c^{-}}\right)}{\overline{c^{+}}-\overline{c^{-}}},
$$

where $\Delta F_{c}, \Delta \sigma_{w}, \Delta \beta$, and $\Delta\left(\overline{c^{+}}-\overline{c^{-}}\right)$are the absolute systematic errors in $F_{c}, \sigma_{w}, \beta$, and $\left(\overline{c^{+}}-\overline{c^{-}}\right)$, respectively. The three terms at the right-hand side of Eq. (2) are estimated to be less than $2 \%, 5 \%$, and $3 \%$, respectively (Xu, 2001). Therefore, the accuracy for the flux measurements is estimated to be better than $10 \%$.

The relative random error in $F_{c}$ is given by

$$
\frac{\delta_{F_{c}}}{F_{c}}=\sqrt{\left(\frac{\delta_{\sigma_{w}}}{\sigma_{w}}\right)^{2}+\left(\frac{\delta_{\beta}}{\beta}\right)^{2}+\left(\frac{\delta\left(\overline{c^{+}}-\overline{c^{-}}\right)}{\overline{c^{+}}-\overline{c^{-}}}\right)^{2}},
$$

where $\delta_{F_{c}}, \delta_{\sigma_{w}}, \delta_{\beta}$, and $\delta_{\left(\overline{c^{+}}-\overline{c^{-}}\right)}$are the absolute random errors in $F_{c}, \sigma_{w}, \beta$, and $\left(\bar{c}^{+}-\overline{c^{-}}\right)$, respectively. Detailed considerations $(\mathrm{Xu}, 2001)$ show that $\delta_{\left(\overline{c^{+}}-\overline{c^{-}}\right)} /\left(\overline{c^{+}}-\overline{c^{-}}\right)$is normally dominant among the three error sources at the righthand side of Eq. (3). Because of the relatively small $\left|\overline{c^{+}}-\overline{c^{-}}\right|$ values, and the less perfect precision in the GC measurements of COS and $\mathrm{CS}_{2}, \delta_{\left.\overline{\left(c^{+}\right.}-\overline{c^{-}}\right)} /\left(\overline{c^{+}}-\overline{c^{-}}\right)$was as large as $10-100 \%$ in most REA runs. In a few extreme cases, when 
Table 1. REA measurements of $\mathrm{COS}, \mathrm{CS}_{2}$ and $\mathrm{CO}_{2}$ fluxes over a spruce forest in Solling, Germany. Mean values and standard errors of the mean are listed for the individual campaigns

\begin{tabular}{clll}
\hline Time & $\begin{array}{l}F_{C O S} \\
\mathrm{pmol} \mathrm{m}^{-2} \mathrm{~s}^{-1}\end{array}$ & $\begin{array}{l}F_{C S_{2}} \\
\mathrm{pmol} \mathrm{m}^{-2} \mathrm{~s}^{-1}\end{array}$ & $\begin{array}{l}F_{C O_{2}} \\
\mu \mathrm{mol} \mathrm{m}^{-2} \mathrm{~s}^{-1}\end{array}$ \\
\hline Aug. 1997 & $-105 \pm 47$ & $-44 \pm 37$ & no data \\
Sept. 1997 & $-173 \pm 51$ & $-17 \pm 8$ & no data \\
Sept. 1998 & $-43 \pm 27$ & $-32 \pm 20$ & $-5.98 \pm 0.81$ \\
May 1999 & $-93 \pm 32$ & $1 \pm 20$ & $-10.2 \pm 1.4$ \\
Jul. 1999 & $-88 \pm 19$ & $5 \pm 9$ & $-9.29 \pm 1.03$ \\
Sep./Oct. 1999 & $-105 \pm 23$ & $-36 \pm 19$ & $-5.06 \pm 1.26$ \\
\hline
\end{tabular}

the fluxes (or the $\left|\overline{c^{+}}-\overline{c^{-}}\right|$values) were close to zero, it was even larger than $1000 \%$. Consequently, with a few exceptions, random errors in $\sigma_{w}$ and $\beta$ contribute only negligibly to the overall precision of the $\mathrm{COS}$ and $\mathrm{CS}_{2}$ fluxes. $\mathrm{CO}_{2}$ could be measured at higher precision than sulfur gases. In spite of the small differences between $\overline{c^{+}}$and $\overline{c^{-}}$for $\mathrm{CO}_{2}$, the relative random error in $\left(\overline{c^{+}}-\overline{c^{-}}\right)$for $\mathrm{CO}_{2}$ was smaller than $10 \%$ in most cases. This is about the same order of magnitude as the relative random errors in $\sigma_{w}$ and $\beta$.

\section{Results and discussion}

\subsection{Validation of the REA sampler}

To verify the reliability of the REA sampler, $\mathrm{CO}_{2}$ flux measurements were intercompared with those from EC measurements by IFB. 94 pairs of $\mathrm{CO}_{2}$ fluxes measured simultaneously by REA and EC techniques are plotted in Fig. 4. Although there are some outliers, the overall agreement is good. The regression line indicates a slight overestimate of the $\mathrm{CO}_{2}$ deposition flux by REA. Considering the standard errors of the intercept and the slope, 0.55 and 0.06 , respectively, this overestimate is not significant. The $95 \%$ confidence belt covers the 1:1 line, suggesting a reliable performance of the REA system under most conditions.

\section{2 $\mathrm{COS}$ and $\mathrm{CS}_{2}$ fluxes}

Six campaigns of 10 to 15 days were conducted in August and September of 1997, in September of 1998, and in May, July and September-October of 1999, respectively. The observed fluxes ranged from -497 to $311 \mathrm{pmol} \mathrm{m}^{-2} \mathrm{~s}^{-1}$ for COS and from -305 to $236 \mathrm{pmol} \mathrm{m}^{-2} \mathrm{~s}^{-1}$ for $\mathrm{CS}_{2}$, indicating that the spruce forest can both take up and emit $\mathrm{COS}$ as well as $\mathrm{CS}_{2}$. Uptake of both gases occurred mainly during the sunlit period, whereas emission was observed mostly at night (see Sect. 3.4 for details). On the average, the forest is a sink for atmospheric COS and $\mathrm{CS}_{2}$. The average fluxes are $-93 \pm 11.7 \mathrm{pmol} \mathrm{m}^{-2} \mathrm{~s}^{-1}$ for COS and $-18 \pm 7.6 \mathrm{pmol} \mathrm{m}^{-2} \mathrm{~s}^{-1}$ for $\mathrm{CS}_{2}$.
Soil chamber measurements at the site showed that the soil always acted as a sink for atmospheric COS (Steinbacher, 2000). However, based on the average flux of $-0.81 \pm 0.24 \mathrm{pmol} \mathrm{m}^{-2} \mathrm{~s}^{-1}$, the soil sink of COS accounts for only less than $1 \%$ of the mean deposition of COS into the ecosystem, as observed in the REA measurements. The airsoil exchange of $\mathrm{CS}_{2}$, ranging from $-0.11 \mathrm{pmol} \mathrm{m}^{-2} \mathrm{~s}^{-1}$ to $0.23 \mathrm{pmol} \mathrm{m}^{-2} \mathrm{~s}^{-1}$, is also negligibly small compared to the exchange flux of $\mathrm{CS}_{2}$ between the forest and the atmosphere. Therefore, the COS and $\mathrm{CS}_{2}$ fluxes observed by the REA technique are mainly caused by the air-vegetation exchange.

For the purpose of comparison, the values of the observed deposition fluxes of COS and $\mathrm{CS}_{2}$ were converted to deposition velocities relative to the leaf area. The deposition velocity for COS averaged $1.1 \pm 0.7 \mathrm{~mm} \mathrm{~s}^{-1}$. This agrees well with deposition velocities obtained in other laboratory and in situ studies (Taylor et al., 1983; Kluczewski et al., 1985; Goldan et al., 1988; Kesselmeier and Merk, 1993; Huber, 1994; Kuhn, 1997) although quite different plant species were investigated in most of these studies. The deposition velocity for $\mathrm{CS}_{2}$ averaged $5.4 \pm 5.9 \mathrm{~mm} \mathrm{~s}^{-1}$. $\mathrm{CS}_{2}$ deposition velocities reported by Huber (1994) and Taylor et al. (1983) range from 0 to $1.5 \mathrm{~mm} \mathrm{~s}^{-1}$.

\subsection{Seasonal variations}

Field experiments covered the seasons of spring, summer and fall. Because of unsuitable weather conditions (cold, snow coverage, etc.), no field experiment was carried out in the winter months. Table 1 lists statistical data for the REA measurements of COS and $\mathrm{CS}_{2}$ fluxes in different seasons and years. Data for $\mathrm{CO}_{2}$ fluxes are also presented in this table.

During all seasons, COS on the average was taken up by the forest, although emission was observed sometimes during individual measurements. The largest COS deposition was observed in September of 1997, the smallest in September of 1998. There is no clear seasonal variation of the COS flux due to the large year-to-year fluctuation in fall. $\mathrm{CS}_{2}$ flux data show a net deposition in August, September and October and a minor, but insignificant net emission in May and July. The 


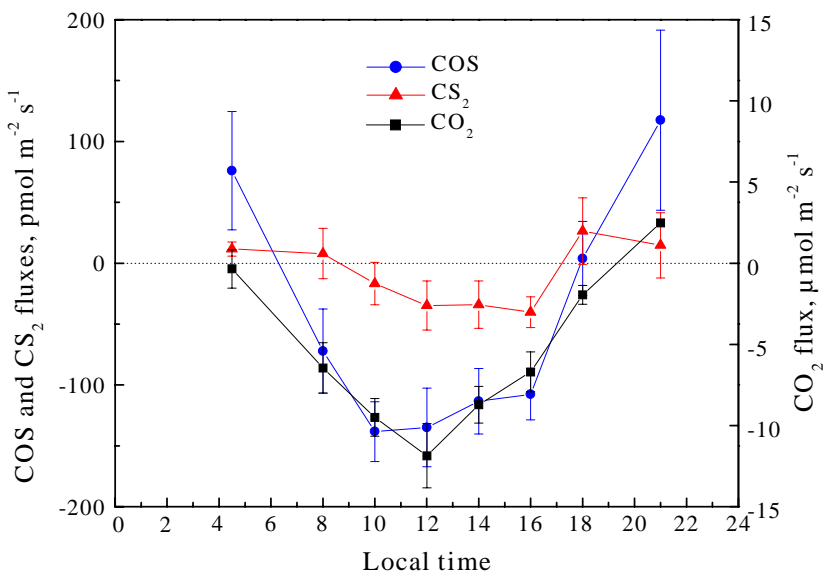

Fig. 5. Average diurnal variation in the $\mathrm{COS}, \mathrm{CS}_{2}$ and $\mathrm{CO}_{2}$ fluxes. The error bars indicate standard errors of the mean.

$\mathrm{CO}_{2}$ flux data show a clear seasonal variation, with larger $\mathrm{CO}_{2}$ deposition observed in later spring and in summer, and a smaller deposition in fall. This seasonal variability is consistent with the continuous measurements of $\mathrm{CO}_{2}$ flux at the same site (Ibrom et al., 1996).

\subsection{Diurnal variations}

Because of the high variability of the $\mathrm{COS}$ and $\mathrm{CS}_{2}$ fluxes and the small number of measurements which could be performed on an individual day, it is difficult to identify any potential diurnal variation of the $\mathrm{COS}$ and $\mathrm{CS}_{2}$ fluxes on the basis of data for individual observational days. Such data do not always show any common features. Some daily profiles are even contradictory. However, the average diurnal variations, presented in Fig. 5, clearly indicate systematic features of the fluxes of COS and $\mathrm{CS}_{2}$, as well as of $\mathrm{CO}_{2}$. It is obvious that $\mathrm{COS}$ and $\mathrm{CS}_{2}$ are taken up by the forest predominantly during the sunlit hours, and that the release of these gases occurs during the rest of the day, similarly to $\mathrm{CO}_{2}$. The strongest deposition of both sulfur gases was observed around local noon, i.e. during the period with most intense solar radiation and strongest turbulence. The similar diurnal features for $\mathrm{COS}$ and $\mathrm{CO}_{2}$ suggest the existence of a common uptake pathway, i.e. the open stomata, as suggested by Goldan et al. (1988). The change of stomatal aperture, which is controlled by various environmental factors, such as the light intensity, water stress, etc., may cause the diurnal cycles of the $\mathrm{COS}$ and $\mathrm{CS}_{2}$ fluxes, as it does for the $\mathrm{CO}_{2}$ flux. This is supported by the correlations shown in the following sections.

\subsection{Correlations to PAR and to the $\mathrm{H}_{2} \mathrm{O}$ flux}

Figures 6a and $\mathrm{b}$ show the relationships of the COS flux to photosynthetically active radiation (PAR) and to the $\mathrm{H}_{2} \mathrm{O}$ flux, respectively. The correlation coefficients in the figures
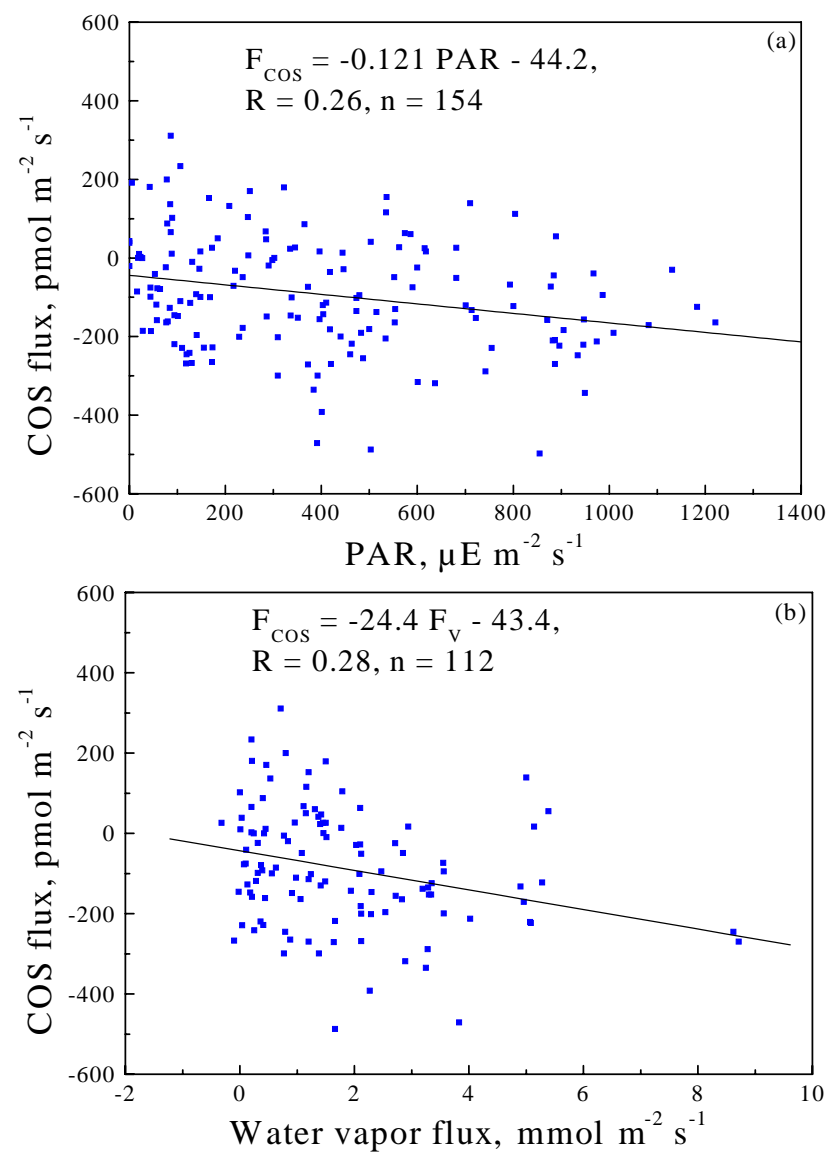

Fig. 6. Correlation of the COS flux to (a) photosynthetically active radiation (PAR) and (b) the $\mathrm{H}_{2} \mathrm{O}$ flux $\left(\mathrm{F}_{V}\right)$.

indicate that the COS flux is significantly $(\alpha<0.01)$ correlated both to PAR and to the $\mathrm{H}_{2} \mathrm{O}$ flux.

As implied by the slopes of the regression lines in Figs. 6a and $6 \mathrm{~b}$, the uptake of COS increases with increasing PAR and $\mathrm{H}_{2} \mathrm{O}$ flux. This may be a result of physiological regulation through stomatal aperture, which is related to both PAR and the $\mathrm{H}_{2} \mathrm{O}$ flux. At higher PAR, the trees tend to take up more $\mathrm{COS}$ and $\mathrm{CS}_{2}$ and release more water vapor, because of decreased stomatal resistance. Although the relationships of Fig. 6 between the COS flux and physiological parameters are plausible, they are not suitable for parameterization purposes, since the correlations capture only a very small fraction $(<10 \%)$ of the variance.

The $\mathrm{CS}_{2}$ flux is also correlated to PAR and the $\mathrm{H}_{2} \mathrm{O}$ flux. However, both correlations are only significant at confidence levels of $75 \%$ and $87 \%$, respectively. There is no known enzymatic mechanism which can explain the deposition of $\mathrm{CS}_{2}$ to plants and the slight correlations of the $\mathrm{CS}_{2}$ flux to PAR and the $\mathrm{H}_{2} \mathrm{O}$ flux. 
Table 2. Measurements of the uptake of COS by different plants in relation to $\mathrm{CO}_{2}$ assimilation

\begin{tabular}{llll}
\hline Plant & $\mathrm{COS} / \mathrm{CO}_{2}\left(\mathrm{pmol} \mu \mathrm{mol}^{-1}\right)$ & Method & Reference \\
\hline Spruce & $10.0 \pm 1.7$ & REA, in situ & This work \\
\hline Spruce & $11.7 \pm 4.8$ & Chamber, in situ & Huber (1994) \\
\hline Quercus agrifolia & 2.2 & Chamber, in situ & Kuhn (1997) \\
\hline Spruce & $0.8 \pm 0.1$ & Gradient, in situ & Hofmann (1993) \\
Wheat & $5.7 \pm 1.0$ & Chamber, in situ & \\
Corn & $11.2 \pm 3.8$ & & \\
Pea & $6.2 \pm 2.1$ & & \\
\hline Pea & $0.3-4.2$ & Chamber, laboratory & Kesselmeier and Merk (1993) \\
Rapeseed & $0.9-1.4$ & & \\
Corn & $1.9-16.7$ & Chamber, in situ & Kesselmeier et al. (1993) \\
\hline Sacoglottis gabonensis & $14.4(0.8-38.4)$ & & \\
Porterandia cladantha & $1.7(0.14-6.0)$ & Chamber, laboratory & Velmeke (1993) \\
\hline Querscus petrea & 2.2 & & \\
\hline
\end{tabular}

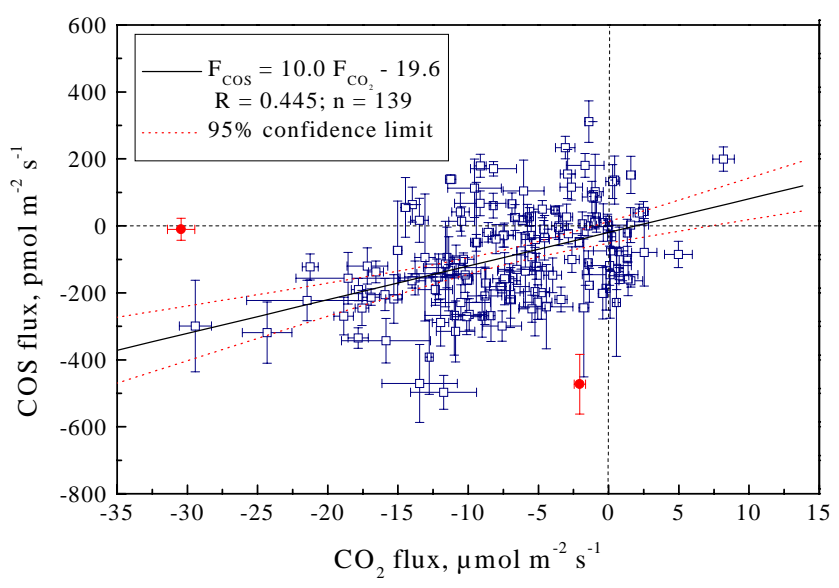

Fig. 7. Correlation between the $\mathrm{COS}$ and $\mathrm{CO}_{2}$ fluxes. The vertical and horizontal bars present the estimated errors of the observed $\mathrm{COS}$ and $\mathrm{CO}_{2}$ fluxes. The two outliers marked with filled circles were not included in the regression since the results are too sensitive to them.

\subsection{Correlation to the $\mathrm{CO}_{2}$ flux}

Laboratory studies show that COS is consumed by plants in nearly the same way as $\mathrm{CO}_{2}$, after being split by the key enzyme, CA (Protoschill-Krebs and Kesselmeier, 1992; Protoschill-Krebs et al., 1995, 1996). This finding not only reveals the physiological background of the uptake of COS by higher plants, but also implies the possibility of extrapolating these measurements to obtain the global COS deposition to vegetation, using the ratio of the COS uptake to $\mathrm{CO}_{2}$ assimilation and the global $\mathrm{CO}_{2}$ fixation, which is better quantified. Measurements performed during this work sup- port this idea. Figure 7 shows that the $\mathrm{COS}$ and $\mathrm{CO}_{2}$ fluxes are positively correlated at the $99 \%$ confidence level. Although the data points are relatively scattered, the correlation line is well defined, as indicated by the dotted lines of the $95 \%$ confidence belt of the regression line.

The regression line in Fig. 7 contains a small intercept $\left(-19.6 \mathrm{pmol} \mathrm{m}^{-2} \mathrm{~s}^{-1}\right)$. Both the intercept and the origin lie within the $95 \%$ confidence belt, suggesting that the deviation of this intercept from the origin is not significant. This is consistent with the idea that both $\mathrm{COS}$ and $\mathrm{CO}_{2}$ are exchanged between the atmosphere and vegetation through a common pathway, i.e. the open stomata. Because the flux measurements were made at $39 \mathrm{~m}$ above the ground, the observed $\mathrm{CO}_{2}$ flux contains contributions not only from the airvegetation exchange, but also from heterotrophic respiration $\left(R_{h}\right)$ and the storage $(S)$ of $\mathrm{CO}_{2}$ between the ground and 39 $\mathrm{m}$ height. The combined contribution of heterotrophic respiration and storage $\left(R_{h}-S\right)$ can cause an intercept in the regression line, and even a larger slope than the air-vegetation exchange alone, if the observed $\mathrm{CO}_{2}$ flux is anti-correlated with $\left(R_{h}-S\right)$ (see M. Heimann, Interactive comment; Xu et al., Final response). Since data from this study do not suggest existence of the anti-correlation, the slope (10.0 with a standard deviation of 1.7) of the regression line in Fig. 7 can be considered as a representative value for the ratio of the $\mathrm{COS}$ - and $\mathrm{CO}_{2}$-uptake at the site.

The uptake ratio $\mathrm{COS} / \mathrm{CO}_{2}$ was also investigated in several laboratory as well as in situ studies (Hofmann, 1993; Kesselmeier and Merk, 1993; Kesselmeier et al., 1993; Velmeke, 1993; Huber, 1994; Kuhn, 1997). Table 2 lists various values of uptake ratios which were reported in these articles, along with the one obtained in this work. Considerable differences exist between the uptake ratios reported 
for different plant species, and even between various values reported for spruce. Hofmann (1993) and Huber (1994) measured exchanges of $\mathrm{COS}$ and $\mathrm{CO}_{2}$ between the atmosphere and a spruce forest (80 years) in Schachtenau (Nationalpark Bayerischer Wald), Germany, using the gradient and chamber methods, respectively. The uptake ratio obtained in the present work agrees reasonably well with the one derived from the measurements of Huber (1994), but it is about one order of magnitude larger than that derived by Hofmann (1993). If compared with the other uptake ratios listed in Table 2, our results fall roughly into the middle of all values reported so far.

\subsection{Extrapolation to global vegetation sinks}

One of the goals of the present work was to derive an estimate of the global vegetation sink of atmospheric COS by extrapolating the ratio between $\mathrm{COS}$ uptake and $\mathrm{CO}_{2}$ fixation from the flux measurements. As shown in Sect. 3.6, a correlation of the $\mathrm{COS}$ flux to $\mathrm{CO}_{2}$ flux was obtained for the spruce forest. The measurements of Hofmann (1993) and Huber (1994) on a 80 year spruce stand also showed a significant correlation between the $\mathrm{COS}$ and $\mathrm{CO}_{2}$ fluxes. However, such a correlation was not found during cuvette experiments on young (10 years) spruce trees (Huber, 1994). A poor correlation between the $\mathrm{COS}$ exchange and the $\mathrm{CO}_{2}$ assimilation was also found by Kesselmeier et al. (1993) during field experiments on tropical plants (Poterandia cladantha and Saccoglottis gabonensis), while a good correlation was observed by Kuhn (1997) during experiments on a temperate plant (Quercus agrifolia). Laboratory studies on agricultural plants (wheat, corn, rapeseed and pea) showed a certain correlation of the $\mathrm{COS}$ uptake to the $\mathrm{CO}_{2}$ assimilation (Hofmann, 1993; Kesselmeier and Merk, 1993), while no relationship between $\mathrm{COS}$ and $\mathrm{CO}_{2}$ exchanges was observed over a wheat field (Hofmann, 1993). The inconsistency among these results indicates the uncertainty of any estimates of the global COS vegetation sink based on extrapolation. Nevertheless, it is worthwhile to use this extrapolation method until better methods become available. Based on the uptake ratio $\mathrm{COS} / \mathrm{CO}_{2}$ of $10.0 \pm 1.7 \mathrm{pmol} \mu \mathrm{mol}^{-1}$ obtained in this work and the recent estimate of the terrestrial net primary production (NPP) of about $45 \pm 5 \mathrm{Pg} \mathrm{C} \mathrm{yr}^{-1}$

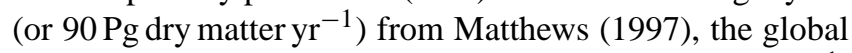
vegetation sink is estimated to be $2.3 \pm 0.5 \mathrm{TgCOS} \mathrm{yr}^{-1}$.

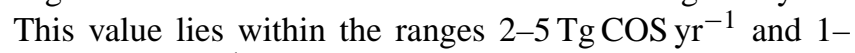
3.4 $\mathrm{Tg} \mathrm{COS} \mathrm{yr}^{-1}$ estimated by Brown and Bell (1986) and Hofmann (1993), respectively, but is much larger than the estimates of $0.24-0.59 \mathrm{Tg} \mathrm{COS} \mathrm{yr}^{-1}, 0.16-1.0 \mathrm{Tg}^{\mathrm{COS}} \mathrm{yr}^{-1}$

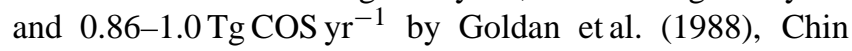
and Davis (1993), and Kesselmeier and Merk (1993), respectively. The COS vegetation uptake derived from our REA measurements should not be considered as the current best estimate of this sink. While its uncertainty of $\pm 0.5 \mathrm{TgCOS} \mathrm{yr}^{-1}$ is due to the scatter of the REA data and the uncertainty in the NPP estimate, the total error in the extrapolation is unknown and maybe large. A plausible range for the uptake ratio (see Table 2) seems to be $2-12 \mathrm{pmol} \mathrm{mol}^{-1}$, corresponding to a sink of $0.5-$ $2.8 \mathrm{TgCOS} \mathrm{yr}^{-1}$. The figure obtained in this work falls within this range. However, as it is derived from a large number of in situ data covering several years and seasons, it should be given special consideration.

The above method can also be applied to tentatively estimate the vegetation sink of $\mathrm{CS}_{2}$. A linear fit shows $F_{C S_{2}}=$

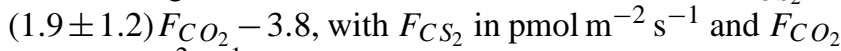
in $\mu \mathrm{mol} \mathrm{m}{ }^{-2} \mathrm{~s}^{-1}$. Assuming that the uptake ratio $\mathrm{CS}_{2} / \mathrm{CO}_{2}$ is equal to $1.9 \pm 1.2 \mathrm{pmol} \mu \mathrm{mol}^{-1}$, the global vegetation sink is estimated to be $0.54 \pm 0.35 \mathrm{TgCS}_{2} \mathrm{yr}^{-1}$. However, this preliminary estimate of the vegetation sink of atmospheric $\mathrm{CS}_{2}$ should be viewed with caution since the correlation between the $\mathrm{CS}_{2}$ and $\mathrm{CO}_{2}$ fluxes is only significant at the $90 \%$ confidence level. Considering the large uncertainty in this estimate, further studies are necessary to quantify the airvegetation exchange of $\mathrm{CS}_{2}$.

\section{Conclusions}

A REA sampler for measuring gas fluxes over forests has been developed and validated. Exchange fluxes of COS and $\mathrm{CS}_{2}$ between a tall spruce forest and the atmosphere were measured using this system. Both deposition and emission of $\mathrm{COS}$ and $\mathrm{CS}_{2}$ were observed. On the average, however, the forest acted as a net sink of both gases. The average fluxes for $\mathrm{COS}$ and $\mathrm{CS}_{2}$ were $-93 \pm 11.7 \mathrm{pmol} \mathrm{m}^{-2} \mathrm{~s}^{-1}$ and $-18 \pm 7.6 \mathrm{pmol} \mathrm{m}^{-2} \mathrm{~s}^{-1}$, respectively. The uptake of COS by the forest showed no clear seasonal pattern. A net deposition of $\mathrm{CS}_{2}$ was observed in August, September and October and a minor net emission in May and July. On the average, a maximum deposition is found around noon, indicating the importance of stomata in controlling the air-plant exchange of COS and $\mathrm{CS}_{2}$. This is supported by the correlations of the fluxes of both gases to PAR and to the $\mathrm{H}_{2} \mathrm{O}$ and $\mathrm{CO}_{2}$ fluxes. Based on the uptake ratio $\mathrm{COS} / \mathrm{CO}_{2}\left(10.0 \pm 1.7 \mathrm{pmol} \mu \mathrm{mol}^{-1}\right)$ and a recent estimate of the NPP, the global COS vegetation sink

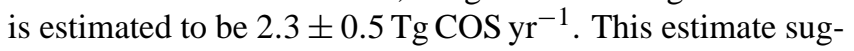
gests that the vegetation sink of COS may have been significantly underestimated in earlier budget reviews of atmospheric COS. Since the tropospheric burden of COS is about $4.6 \mathrm{Tg}$, such a large vegetation sink of COS may limit the residence time of atmospheric COS to about 2 years and cause significant seasonal variations in the mixing ratio of tropospheric COS at the middle and high latitudes of the Northern Hemisphere.

Acknowledgements. This work was funded by the Deutsche Forschungsgemeinschaft (DFG) through grant BI 462/1-3. We are very grateful to Drs. K. Morgenstern, A. Ibrom and others from the Institute for Bioclimatology, University of Göttigen for their 
kind supports. We thank Graeme Handisides for improving the manuscript.

\section{References}

Adams, D. F., Farwell, S. O., Pack, M. R., and Robinson, E.: Biogenic sulfur gas emissions from soils in eastern and southern United States, J. Air Pollut. Cont. Ass., 31, 1083-1089, 1981.

Andreae, M. O. and Crutzen, P. J.: Atmospheric aerosols: Biogeochemical sources and role in atmospheric chemistry, Science, 276, 1052-1058, 1997.

Bartell, U., Hofmann, U., Kreuzburg, B., Andreae, M.O., and Kesselmeier, J.: COS and $\mathrm{H}_{2} \mathrm{~S}$ fluxes over a wet meadow in relation to photosynthetic activity: An analysis of measurements made on 6 September 1990, Atmos. Environ., 27, 1851-1864, 1993.

Berresheim, H. and Vulcan, V. D.: Vertical distributions of COS, $\mathrm{CS}_{2}$, DMS and other sulfur compounds in a loblolly pine forest, Atmos. Environ., 26 (11), 2031-2036, 1992.

Beverland, I. J., Moncrieff, J. B., ÓNéill, D. H., Hargreaves, K. J., and Milne, R.: Measurement of methane and carbon dioxide fluxes from peatland ecosystems by the conditional-sampling technique, Q. J. R. Meteorol. Soc., 122, 819-838, 1996.

Brown, K. A. and Bell, J. N. B.: Vegetation - the missing sink in the global cycle of COS, Atmos. Environ., 20, 537-540, 1986.

Businger, J. A. and Oncley, S. P.: Flux measurement with conditional sampling, J. Atmos. Ocean. Technol., 2, 349-352, 1990.

Castro, M.S. and Galloway, J. N.: A comparison of sulfur-free and ambient air enclosure techniques for measuring the exchange of reduced sulfur gases between soils and the atmosphere, J. Geophys. Res., 96, 15 427-15 437, 1991.

Chin, M. and Davis, D. D.: Global sources and sinks of OCS and $\mathrm{CS}_{2}$ and their distributions, Global Biogeochem. Cycles, 7, 321337, 1993.

Crutzen, P. J.: The possible importance of CSO for the sulfate layer of the stratosphere, Geophys. Res. Lett., 3, 73-76, 1976.

den Hartog, G. D. and Neumann, H. H.: An empirical study on dry deposition of air pollutants to forests, Tech. Rep. AQRB-84-011L, AES, Canada, 1984.

Dippel, J. and Jaeschke, W.: A comparison between natural and anthropogenic emissions of the reduced sulfur compounds $\mathrm{H}_{2} \mathrm{~S}$, $\mathrm{COS}$, and $\mathrm{CS}_{2}$ in a tropical industrialized region, J. Atmos. Chem., 25, 251-270, 1996.

Ellenberg, H., Mayer, R., and Schauermann, J.: Ökosystemforschung - Ergebnisse des Sollingprojektes 19661986, Verlag Eugen Ulmer, Stuttgart, 1986.

Engel, A. and Schmidt, U.: Vertical profile measurements of carbonylsulfide in the stratosphere, Geophys. Res. Lett., 21, 22192222, 1994.

Fall, R., Albritton, D. L., Fehnsenfeld, F.C., Kuster, W.C., and Goldan, P. D.: Laboratory studies of some environmental variables controlling sulfur emissions from plants, J. Atmos. Chem., 6, 341-362, 1988.

Fried, A., Klinger, L. F., and Erickson, III, D. J.: Atmospheric COS exchange in bog microcosms, Geophys. Res. Lett., 20 (2), 129132, 1993.

Goldan, P. D., Kuster, W. C., Albritton, D. L., and Fehsenfeld, F. C.: The measurement of natural sulfur emissions from soil and veg- etation: Three sites in the Eastern United States revisited, J. Atmos. Chem., 5, 439-467, 1987.

Goldan, P.D., Fall, R., Kuster, W.C., and Fehnsenfeld, F. C.: Uptake of COS by growing vegetation: A major tropospheric sink, J. Geophys. Res., 93, 14 186-14 192, 1988.

Grainier, C. and Brasseur, G.: Impact of heterogeneous chemistry on model predictions of ozone changes, J. Geophys. Res., 97 (D16), 18 015-18 033, 1992.

Hines, M.E. and Morrison, M.C.: Emission of biogenic sulfur gases from Alaskan tundra, J. Geophys. Res., 97 (D15), $16703-$ 16707, 1992.

Hofmann, U.: Vergleichende Untersuchungen zum Austausch von reduzierten Schwefelverbindungen zwischen Vegetation und Atmosphäre im Feldversuch und unter kontrollierten Bedingungen, Ph.D. thesis, Universität Mainz, 1993.

Hofmann, U., Hofmann, R., and Kesselmeier, J.: Field measurements of reduced sulfur compounds over wheat during a growing season, in: Precipitation scavenging and atmosphere-surface exchange. Volume 2: Atmosphere-Surface Exchange Processes, (Eds) Schwartz, S. E. and Slinn, W. G. N., 967-977, Hemisphere, Washington, D. C., 1992.

Huber, B.: Austausch flüchtiger Schwefelverbindungen in landund forstwirtschaftlichen Ökosystemen, Wissenschaftsverlag Maraun, Frankfurt, 1994.

Ibrom, A., Schuetz, C., Tworek, T., Morgenstern, K., Oltchev, A., Falk, M., Constaintin, J., and Gravenhorst, G.: Eddy-correlation measurements of the fluxes of $\mathrm{CO}_{2}$ and $\mathrm{H}_{2} \mathrm{O}$ above a spruce stand, Phys. and Chem. Earth, 21, 409-414, 1996.

Kesselmeier, J. and Merk, L.: Exchange of carbonyl sulfide (COS) between agricultural plants and the atmosphere: Studies on the deposition of COS to peas, corn and rapeseed, Biogeochem., 23, 47-59, 1993.

Kesselmeier, J., Meixner, F. X., Hofmann, U., Ajavon, A.-L., Leimbach, S., and Andreae, M. O.: Reduced sulfur compounds exchange between the atmosphere and tropical tree species in Southern Cameroon, Biogeochem., 23, 23-45, 1993.

Khalil, M. A. K. and Rasmussen, R. A.: Global sources, lifetimes and mass balances of carbonyl sulfide (OCS) and carbon disulfide $\left(\mathrm{CS}_{2}\right)$ in the Earth's atmosphere, Atmos. Environ., 8 (9), 1805-1813, 1984.

Kluczewski, S. M., Bell, J. N. B., Brown, K. A., and Minski, M. J.: The uptake of ${ }^{35} \mathrm{~S}$-carbonyl sulphide by plants and soils, in: Ecological aspects of radionuclide release, Special Publication of British Ecological Society III, (Ed) Coughtrey, P. J., pp. 91-104, Blackwell Scientific Press, Oxford, 1983.

Kluczewski, S. M., Brown, K. A., and Bell, J. N. B.: Deposition of $\left[{ }^{35} \mathrm{~S}\right]$-carbonyl sulphide to vegetable crops, Radiat. Prot. Dosim, 11, 173-177, 1985.

Kuhn, U.: Spurengasaustausch klimarelevanter reduzierter Schwefelverbindungen zwischen Biosphäre und Atmosphäre: COS Transfer der Flechten und anderer biotischer Kompartimente, Ph.D. thesis, Universität Mainz, 1997.

Kuhn, U., Ammann, C., Wolf, A., Meixner, F. X., Andreae, M. O., and Kesselmeier, J.: Carbonyl sulfide exchange on an ecosystem scale: Soil represents a dominant sink for atmospheric COS, Atmos. Environ., 33 (6), 995-1008, 1999.

Lacis, A., Hansen, J., and Sato, M.: Climate forcing by stratospheric aerosols, Geophys. Res. Lett., 19, 1607-1610, 1992.

Lamb, B., Westberh, H., Allwine, G., Bamesberger, L., and Guen- 
ther, A.: Measurement of biogenic sulfur emission from soil and vegetation: Application of dynamic enclosure methods with $\mathrm{Na}-$ tusch filter and GC/FPD analysis, J. Atmos. Chem., 5, 469-491, 1987.

Laubach, J., Raschendorfer, M., Kreilein, H., and Gravenhorst, G.: Determination of heat and water vapour fluxes above a spruce forest by eddy correlation, Agric. For. Meteorol., 71, 373-401, 1994.

Leuning, R. and Moncrieff, J.: Eddy-covariance $\mathrm{CO}_{2}$ flux measurements using open- and closed-path $\mathrm{CO}_{2}$ analysers: Corrections for analyser water vapour sensitivity and damping of fluctuations in air sampling tubes, Bound.-Layer Meteorol., 53, 63-76, 1990.

Matthews, E.: Global litter production, pools, and turnover times: estimates from measurement data and regression models, J. Geophys. Res., 102, 18 771-18 800, 1997.

Mihalopoulos, N., Bonsang, B., Nguyen, B. C., Kanakidou, M., and Belviso, S.: Field observations of COS deficit near the ground: Possible implication of vegetation, Atmos. Environ., 23 (10), 2159-2166, 1989.

Moncrieff, J. B., Beverland, I. J., ÓNéill, D. H., and Cropley, F. D.: Controls on trace gas exchange observed by a conditional sampling method, Atmos. Environ., 32 (19), 3265-3274, 1998.

Oncley, S. P., Delany, A. C., Horst, T. W., and Tans, P. P.: Verification of flux measurement using relaxed eddy accumulation, Atmos. Environ., 27, 2417-2426, 1993.

Pattey, E., Desjardins, R. L., and Rochette, R.: Accuracy of the relaxed eddy-accumulation technique, evaluated using $\mathrm{CO}_{2}$ flux measurements, Bound.-Layer Meteorol., 66, 341-355, 1993.

Pattey, E., Desjardins, R. L., Westberg, H., Lamb, B., and Zhu, T.: Measurement of isoprene emissions over a black spruce stand using a tower-based relaxed eddy-accumulation system, J. Appl. Meteorol., 38 (7), 870-877, 1999.

Protoschill-Krebs, G. and Kesselmeier, J.: Enzymatic pathways for the consumption of carbonyl sulphide (COS) by higher plants, Bot. Acta, 105, 206-212, 1992.

Protoschill-Krebs, G., Wilhelm, C., and Kesselmeier, J.: Consumption of carbonyl sulphide by chlamydomonas reinhardtii with different activities of carbonic anhydrase (CA) induced by different $\mathrm{CO}_{2}$ growing regimes, Bot. Acta, 108, 445-448, 1995.

Protoschill-Krebs, G., Wilhelm, C., and Kesselmeier, J.: Consumption of carbonyl sulphide (COS) by higher plants carbonic anhydrase (CA), Atmos. Environ., 30, 3151-3156, 1996.

Rennenberg, H., Schröder, P., and Huber, B.: Emission of reduced sulfur compounds from agricultural and forest ecosystems, in: EUROTRAC Annual Report 1990, Part 4, BIATEX, pp. 156162, Garmisch-Partenkirchen, 1991.

Rodriguez, J. M., Ko, M. K. W., and Sze, N. D.: Role of heterogeneous conversion of $\mathrm{N}_{2} \mathrm{O}_{5}$ on sulphate aerosols in global ozone loses, Nature, 352, 134-137, 1991.

Steinbacher, M.: Untersuchungen zum Austausch von Carbonylsulfid (COS) über einem Waldökosystem, Master thesis, Universität Frankfurt, 2000.

Steinbacher, M., Bingemer, H. G., and Schmidt, U.: Exchange of $\mathrm{COS}$ and $\mathrm{CS}_{2}$ between forest soil and atmosphere at a site in Central Europe, in preparation, 2002.

Steudler, P. A. and Peterson, B. J.: Annual cycle of gaseous sulfur emissions from a New England spartina alterniflora marsh, Atmos. Environ., 19 (9), 1411-1416, 1985.

Taylor, Jr., G. E., McLaughlin, Jr., S. B., Shriner, D. S., and Slevidge, W. J.: The flux sulfur-containing gases to vegetation, Atmos. Environ., 17, 789-796, 1983.

Valentini, R., Greco, S., Seufert, G., Bertin, N., Ciccioli, P., Cecinato, A., Brancaleoni, E., and Frattoni, M.: Fluxes of biogenic VOC's from Mediterranean vegetation by trap enriched relaxed eddy accumulation, Atmos. Environ., 31(S1), 229-238, 1997.

Velmeke, F.: Versuche zur Korrelation von Photosynthese mit dem Austausch flüchtiger Schwefel-Verbindungen zwischen Bäumen and Atmosphäre, Master thesis, Universität Mainz, 1993.

Watts, S. F.: The mass budgets of carbonyl sulfide, dimethyl sulfide, carbon disulfide and hydrogen sulfide, Atmos. Environ., 34, 761779, 2000.

$\mathrm{Xu}, \mathrm{X}$.: Investigations into the Tropospheric Cycle of COS: Atmospheric Distribution, Air-Sea and Air-Vegetaion Exchanges, Ph.D. thesis, Unversität Frankfurt, 2001. 